IVANA PANTELIĆ, istraživač-saradnik

Institut za savremenu istoriju

Beograd, Trg Nikole Pašića 11

UDK 316.662-055.2(497.1)"1945/1953"

\title{
OSVAJANJE NEOSVOJIVOG: POLITIČKA EMANCIPACIJA ŽENA U POSLERATNOJ JUGOSLAVIJI 1945-1953*
}

\begin{abstract}
APSTRAKT: $U$ članku je predstavljeno sticanje političkih prava žena $u$ posleratnoj jugoslovenskoj državi. Sticanjem prava glasa ženama je prvi put omogućeno da postanu vidljive i aktivne u političkoj sferi. Upotrebom statističkih podataka, arhivske građe, savremene periodike, usmenih izvora predstavljen je stepen prisutnost $u$ državnim institucijama, a kroz rad Antifašističkog fronta žena Jugoslavije i aktivizam prvih jugoslovenski političarki.
\end{abstract}

Ključne reči: žene, politička emancipacija, pravo glasa, Komunistička partija Jugoslavije, Antifašistički front žena Jugoslavije

Razdoblje 1944-1948. obeležila je ubrzana izgradnja realsocijalističkog režima. Žene su imale važnu ulogu u ovom procesu. Nizom zakona u Jugoslaviji i njenim novouspostavljenim republikama, po uzoru na rešenja primenjena u Sovjetskom Savezu, žene su teoretski potpuno izjednačene sa muškarcima. Emancipacija žena, kao i reforme države, privrede i socijalne politike, sprovođena je uz pomoć Komunističke partije i vojske. Bivši partizani i partizanke su i dalje bili okosnica i glavna snaga pomoću koje su vršene ove promene. Po završetku Drugog svetskog rata, u maju 1945. dolazi do postepene demobilizacije Narodnooslobodilačke vojske (NOV) i njenog pretvaranja u mirnodopsku armiju. Velika većina od 75.000 partizanki $u$ to vreme bila je demobilisana. Demobilisani pripadnici i pripadnice NOV-a tokom prvih posleratnih godina $u$ velikom broju su se doselili $u$ gradove. Reč je o prvom talasu prelaska stanovništva iz sela u gradove i, svakako, najvećem samostalnom prelasku žena u gradove $u$ dotadašnjoj istoriji Jugoslavije.

* Rad je deo projekta Srpsko društvo u jugoslovenskoj državi u 20. veku: između demokratije i diktature (177016), koji finansira Ministarstvo prosvete, nauke i tehnološkog razvoja Republike Srbije. 
Članom 24 Ustava FNR Jugoslavije iz 1946. godine žene su izjednačene sa muškarcima „u svim oblastima državnog, privrednog i društvenopolitičkog života. Za jednak rad žene imaju pravo na jednaku platu kao i muškarci i uživaju posebnu zaštitu u radnom odnosu. Država naročito štiti interese matere i deteta osnivanjem porodilišta, dečijih domova i obdaništa i pravom matere na plaćeno otsustvo pre i posle porođaja.". ${ }^{1}$ Ovaj član Ustava novoosnovane države gotovo je u potpunosti preuzet iz 122. člana Ustava SSSR-a iz 1936. godine. ${ }^{2}$ Žene su prvi put učestvovale na izborima 1945. godine. Dato im je puno - aktivno i pasivno - biračko pravo. Zakonom o biračkim spiskovima dato je biračko pravo svim državljanima i državljankama Jugoslavije starijim od 18 godina. Svi vojnici Jugoslovenske armije i bivši partizani i partizanke dobili su pravo glasa bez obzira na godine. Član 4 ovog zakona oduzimao je pravo glasa u slučaju osam kategorija građana. Jedna od njih, kojom je biračko pravo oduzimano osuđenim licima, mogla se odnositi i na žene. ${ }^{3} \mathrm{Na}$ ovaj način u Srbiji je veliki broj građanki i građana bio lišen biračkog prava. Branko Petranović iznosi podatak o tome da je samo u Beogradu broj građana predloženih za brisanje iz biračkih spiskova iznosio između 5.000 i 6.000 , odnosno $2,5 \%$. ${ }^{4}$ Žene su u tri sreza Beogradskog okruga (Mladenovački, Kolubarski i Podunavski) činile između 15\% (u Kolubarskom srezu) i 30\% (u Mladenovačkom srezu) građana lišenih biračkog prava. ${ }^{5}$

Sećanja naših sagovornica na izbore uglavnom su saglasna i pozitivna: „Žene su bile vrlo solidarne sa onim što je partija predlagala, bile su vrlo aktivne, njima se mililo da rade. I da čuvaju kutije, i da dežuraju. Da uspe ono za šta smo se mi borili. Eto tako ih ja pamtim. ${ }^{\text {" }}$ Tako su na izborima za Ustavotvornu skupštinu FNRJ održanim 11. novembra 1945, i kasnije na izborima za skupštine narodnih republika, žene prvi put postale poslanice.

${ }^{1}$ Ustav FNRJ, 1946, čl. 24, gl. 5, Prava i dužnosti građana, Službeni list FNRJ, 1. februar 1946, 77; A. Božić, Šta ženama osigurava ustav, Zora, br. 6, februar 1946, 2; B. Mimica, Ravnopravnost žene u ustavu FNRJ, Žena danas, br. 38-39, januar 1946, 1-3; В. ГудацДодић, Жена у соиијализму: йоложај жене у Србији у gруїо йоловини ХХ века, Београд 2006, 10; К. Чавошки, Усйав каосреgстиво ирройайанgе, Београд 2011, 242.

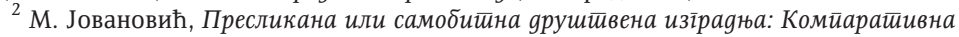
анализа Усйава ФНРЈ (1946) и „Сйальнскої“ Усйава СССР (1936), Токови историје, бр. 1-2, Београд 2008, 287.

B. Petranović, Srbija u Drugom svetskom ratu, 1939-1945, Beograd 1992, 721; M. Mitrović, Žene i represivno zakonodavstvo u Srbiji 1944-1952; Srbija u modernizacijskim procesima, XIX i XX veka, 2, urednik L. Perović, Beograd 1998, 45-46.

${ }^{4}$ B. Petranović, Srbija u Drugom svetskom ratu..., 728.

${ }^{5}$ M. Mitrović, n. d., 46-48.

${ }^{6}$ Razgovor sa Verom Đukić Plavšić, vođen 16. oktobra 2007. 
U Skupštini FNRJ od 537 poslanika oba veća bile su izabrane 22 žene. ${ }^{7}$ Poslanice su činile 4\% ukupnog sastava Skupštine. ${ }^{8}$ U NR Srbiji je među 287 izabranih poslanika bilo deset žena $(3,5 \%)$, i taj broj je procentualno bio niži od učešća poslanica u skupštinama drugih republika.

U institucijama nove vlasti žene su bile zastupljene u meri u kojoj su to bile i u ustanovama partizanske države tokom trajanja rata. ${ }^{9} \mathrm{U}$ Izvršnom odboru Narodnog fronta Jugoslavije, političkog saveza koji je zajedno sa KPJ odneo pobedu na prvim posleratnim izborima, nalazila se jedna žena, partizanka Spasenija Cana Babović. U Plenumu NFJ bilo je osam žena. U Izvršni odbor NF Srbije bile su izabrane dve žene, a u Plenum pet. ${ }^{10}$ Sve one su bile partizanke. Istovremeno, u saveznoj vladi nije bilo žena, dok je u republičkim vladama Srbije, Hrvatske i Slovenije bila po jedna ministarka. Reč je o ministarkama prosvete Mitri Mitrović u NR Srbiji, finansija Anki Berus u NR Hrvatskoj i socijalne politike Vidi Tomšič u NR Sloveniji. Sve tri prve ministarke bile su predratne komunistkinje, a za vreme rata partizanke i pripadnice NOV-a.

Posle formiranja Komunističke partije Srbije 1945. godine, u prvi Centralni komitet KPS bilo je izabrano 43 člana i 6 kandidata. Među njima je bilo 5 žena. ${ }^{11}$ U Politbirou CK KPJ nije bilo žena. Žene nisu bile prisutne ni u politbiroima Komunističke partije SSSR, Čehoslovačke i Poljske, a u drugim komunističkim zemljama ih nije bilo više od dve. ${ }^{12} \mathrm{Za}$ to vreme $\mathrm{u}$ NR Bugarskoj, u Politbirou Bugarske radničke partije (komunista) BRP(k), među 13 članova bila je jedna žena - Cola Dragojčeva. Ona je janu-

${ }^{7}$ M. Stanišić, pozivajući se na fond AFŽJ, navela je kako je iz Srbije u Skupštinu FNRJ izabrano osam poslanica. - M. Stanišić, Društveni položaj žene u Srbiji (1944-1955), neobjavljena magistarska teza, odbranjena na Filozofskom fakultetu Univerziteta u Beogradu, Beograd 2003, 229. Ipak, u fondu Narodni front - Socijalistički savez radnog naroda Jugoslavije navedena su imena pet poslanica (Božidarka Kika Damjanović, Bosa Cvetić, Milka Minić, Stanka Munćan Veselinov, dok su izostavljena imena Mitre Mitrović, Spasenije Cane Babović i Radmile Manojlović).

${ }^{8}$ 141-13-71, AFŽJ, AJ; 142-97-441, NF-SSRNJ, AJ. U Skupštini NR Srbije poslanice su bile: Spasenija Cana Babović, Mitra Mitrović, Ljubinka Milosavljević, Milka Minić, Bosa Cvetić, Miroslava Medić, Ida Sabo, Milka Agbaba, Stanka Veselinov i Dušanka Jovanović.

${ }^{9}$ O jugoslovenskim partizankama u Drugom svetskom ratu videti u: B. JancarWebster, Women and Revolution in Yugoslavia, Denver 1990; B. Wiesinger, Partisaninnen: Widerstand in Yugoslawien (1941-1945), Köln 2008; J. Batinić, Gender, Revolution and the War: The Mobilization of Women in the Yugoslav Partisan Resistance during World War II, neobjavljena doktorska teza odbranjena 2009. na Stanford univerzitetu.

${ }^{10}$ M. Stanišić, $n$. d., 203.

${ }^{11}$ Reč je o 10\% ukupnog broja članova CK KPS. С. Младеновић, Сйасенија Цана Бабовић, Београд-Крагујевац, 1980, 258-259.

${ }^{12}$ M. Molyneux, Women in Socialist Societies, Problems of Theory and Practice, K. Young, C. Wolkowitz, R. McCullagh (edts.) Of Marriage and Market, Women's subordination in international perspective, London 1981, 193. 
ara 1948. smenjena iz članstva u Politbirou, postavši kandidat za člana. Degradirana je pod izgovorom „da je previše isticala svoju ličnost, dok je svim silama radila da baci u zasenak sve druge zaslužne žene" ${ }^{13}$ Treba spomenuti da je juna 1945, prilikom formiranja komisija pri Politbirou CK KPJ, obrazovana i Ženska komisija u kojoj su bile: Mitra Mitrović, Spasenija Cana Babović, Vanda Novosel i Neda Marović, ali se na njenom čelu nalazio Sreten Žujović. ${ }^{14}$

Broj žena u Centralnom komitetu KPS nije se značajno razlikovao od broja i udela članica CK drugih republičkih komunističkih partija. Tako je do 1950. godine u CK KP Hrvatske bilo 6 žena, u istom telu Slovenije 5, $\mathrm{BiH}$ 2, Makedonije 3 i Crne Gore jedna. U BiH i Crnoj Gori nije bilo članica Politbiroa dok je u Hrvatskoj, Sloveniji i Makedoniji bila po jedna žena. ${ }^{15}$ Dakle, udeo žena se posle četiri godine nije značajno promenio. Udeo žena u članstvu CK KPJ bio je nešto manji od $5 \% .{ }^{16}$

U FNRJ je 1950. godine uveden novi tip upravljanja privredom. „Samoupravljanje“ je predstavljalo autohtono jugoslovensko tumačenje Marksovog učenja. Ipak, iako je radnicima formalno predato upravljanje nad privredom i mnogim drugim segmentima društvenog života, monopol KPJ i njenog režima u svim segmentima države i društva nije umanjen. Kada je reč o zastupljenosti žena u najvišim organima vlasti, može se reći da nova decenija i promena političkog kursa nisu doneli značajnije promene. U saveznoj i republičkim vladama uglavnom su bile prisutne ranije birane funkcionerke KPJ i Antifašističkog fronta žena Jugoslavije (AFŽJ), sve bivše partizanke: Spasenija Cana Babović, Milka Minić, Mitra Mitrović i Bosa Cvetić. ${ }^{17}$ Godine 1952. u Izvršnom veću FNRJ među 43 člana bila je jedna žena (2,32\%), u NR Srbiji Izvršno veće je brojalo 26 članova od kojih su dve bile žene $(7,65 \%)$. Srbija je bila među narodnim republikama sa većom zastupljenošću žena u Izvršnom veću, ali treba napomenuti i da su statistike

${ }^{13}$ Zapisnici sa sednica Politbiroa Centralnog komiteta KPJ (11. jun 1945-7. jul 1948), urednik B. Petranović, Beograd 1995, 653-654, 658.

${ }_{14}^{14}$ Zapisnici sa sednica Politbiroa Centralnog komiteta KPJ..., 72.

${ }^{15}$ Brojčani pregled žena u CK KPJ i CK republika, 141-13-71 AFŽJ, AJ., M. Stanišić, n. d., 230 .

${ }^{16}$ Članovi CK KP, Zora, jul 1948, br. 35, 2-4.

${ }^{17}$ U Narodnoj vladi NR Srbije na čijem se čelu nalazio Petar Stambolić (septembar 1948 - april 1951) Mitra Mitrović je u prvo vreme bila ministarka prosvete (do 8. marta 1949), dok je Milka Minić bila predsednica Komiteta za naučne ustanove, univerzitet i više škole. U sledećoj vladi, koja je pod predsedništvom Petra Stambolića upravljala NR Srbijom od aprila 1951. do februara 1953, pored Mitre Mitrović na čelo Ministarstva za narodno zdravlje i socijalnu politiku došla je Spasenija Cana Babović. Konačno, u trećem kabinetu Izvršnom veću NR Srbije - na čijem se čelu nalazio Stambolić, bile su opet prisutne dve žene, bivše partizanke: Spasenija Cana Babović i Bosa Cvetić. P. Љушић, Влаge Србије (1805-2005), Београд 2005, 440-444. 
varljive pošto nigde nije bilo više od dve žene. ${ }^{18}$ Na izborima za Saveznu skupštinu iz 1950, za poslanice je izabrano 30 žena (4,8\%). Prema zvaničnim statistikama, ovo je bilo izvesno povećanje u odnosu na 1946 (22$4,1 \%)$, tri godine kasnije trend povećanja je nastavljen pa je izabrano 28 poslanica $(5,1 \%) .{ }^{19}$

U narednoj deceniji uočen je značajan porast udela žena među poslanicima Savezne skupštine. Tako je 1958. izabrano njih 41 (6,8\%), dok su 1963. žene u Saveznoj skupštini činile čak 1/5 ukupnog broja poslanika, odnosno 131 (19,6\%). U lokalnim predstavničkim telima izabranim 1949. i 1950. odbornici su birani na listama, kasnije, 1953. godine izbori su bili neposredni. Na izborima iz 1949. i 1950. na nivou FNRJ (bez BiH) među 96.579 izabranih odbornika bilo je 10.568 (9,19\%) žena. Žene su činile $3,37 \%$ plaćenih odbornika, u NR Sloveniji ovaj procenat je bio najviši 12,59\%, dok je u NR Srbiji udeo žena u ovoj kategoriji odbornika bio 1,96\%. Od 543 plaćene odbornice u FNRJ (3,37\%), njih 11 je imalo završene fakultete. $^{20}$

Neda Božinović je, ipak, postavila hipotezu kako i takvo prisustvo žena u politici posleratne Jugoslavije nije bilo posledica emancipacije i snage ženskih organizacija, već naprotiv, partijske i državne politike koja je unapred određivala neophodan broj žena u državnim i partijskim organima, i njihovu ulogu. „Društveno-političke organizacije - posebno SKJ i SSRN setile bi se problema ravnopravnosti žena u političkoj sferi neposredno pred same izbore, kada nije preostalo ništa drugo nego da se u nekim razvijenijim sredinama među kandidate ubaci i pokoja žena. ${ }^{\text {21 }}$ Na osnovu sopstvenog iskustva, Neda Božinović, predratna članica KPJ i partizanka, ostavila je sledeće zapažanje o ovom formalnom poštovanju pravila rodne, ali i nacionalne i političke zastupljenosti: „Kad se traži, daj ženu, daj Hrvata, daj borca od 1941, daj ovo, daj ono... ja sam sve to zadovoljavala odjednom." ${ }^{22}$

Telo koje je ženama omogućilo da se samostalno politički organizuju i da kroz njega pokušaju da aktiviraju što veći broj žena bio je Antifašistički front žena Jugoslavije (AFŽJ). U Bosanskom Petrovcu, 1942. godine, održana je Prva zemaljska konferencija AFŽJ, koja je predstavljala i prvo organizovanje na jugoslovenskom nivou. Antifašistički front žena Jugosla-

${ }^{18}$ Žene u izvršnim većima, 141-12-62, AFŽJ, AJ.

${ }^{19} \mathrm{U}$ narednoj deceniji uočen je značajan porast udela žena među poslanicima Savezne skupštine. Tako je 1958. izabrano njih 41 (6,8\%), dok su 1963. žene u Saveznoj skupštini činile čak 1/5 ukupnog broja poslanika, odnosno 131 (19,6\%). Problemi društvenog položaja i aktivnosti žena , Beograd 1965, 18.

${ }^{20}$ Žene u državnoj administraciji, 141-12-62, AFŽJ, AJ.

${ }^{21}$ N. Božinović, Žene u modernizacijskim procesima u Jugoslaviji i Srbiji, Srbija u modernizacijskim procesima XIX i XX veka: položaj žene kao merilo modernizacije, 2, 530.

${ }^{22}$ Neda jedna biografija, priređivač G. Stojaković, Novi Sad 2002, 34. 
vije nastavio je rad i u posleratnom razdoblju. Ipak, ciljevi ove organizacije donekle su bili izmenjeni. Osnovni ciljevi rada, kakvi su definisani na Prvom kongresu održanom u Beogradu od 16. do 19. juna 1945, bili su posvećeni obnovi i humanitarnim aktivnostima. Bosa Cvetić navodi kako su ti zadaci bili sažeti u poziv ženama da „aktivno učestvuju u obnovi zemlje, da pruže svoju pomoć organima vlasti u organizovanju privrednog i društvenog života, u rešavanju socijalnih pitanja, posebno zaštite i zbrinjavanja dece koja su tokom rata ostala bez roditelja." ${ }^{23}$

Jedan od najvažnijih zadataka bio je i prosvećivanje, posebno opismenjavanje ženske populacije. Na prvi pogled, AFŽJ je u prvim posleratnim godinama podsećao na neku žensku humanitarnu organizaciju iz predratnog razdoblja. Ipak, bar tri karakteristike AFŽJ ukazuju na njegovu emancipatorsku ulogu: uloga AFŽJ u mobilisanju žena radi obnove, koja je u posleratnim godinama imala značaj kao i učešće u ratu; doprinos AFŽJ opismenjavanju i prosvećivanju žena; podsticaj koji je AFŽJ dao izgradnji obdaništa, zahvaljujući čemu su žene dobile mogućnost da se zaposle i tako steknu suštinski značajnu ekonomsku samostalnost. ${ }^{24}$ Kao što se može uočiti politička emancipacija nije bila uvrštena u prioritetne aktivnosti AFŽ, što je i razumljivo s obzirom na to da je veliki deo ženske populacije bio nepismen. ${ }^{25}$

Pojedine autorke zastupaju tvrdnju da je AFŽ bio u izvesnoj meri samostalna organizacija. Hrvatska antropološkinja Lidija Sklevicki navodi: „Činjenica da je organizacijsku strukturu moguće prikazati kao piramidu sa širokom bazom (potencijalno je to svaka, 'pa i poslednja žena'), čiji je vrh takođe moguće nedvosmisleno utvrditi, navodi na zaključak da možemo pretpostaviti izvestan stepen organizacijske autonomije. To znači da je postojala mogućnost artikulisanja ciljeva, specifičnijih/autonomnijih od onih koje je Antifašističkom frontu žena poveravala 'narodna' vlast." " 26

Rad AFŽ ipak je u najvećoj meri zavisio od instrukcija koje su stizale iz partije i Narodnog fronta. Da bi žena mogla da zauzme bilo koju funkciju u AFŽ to je prethodno moralo biti odobreno od lokalne partijske vlasti. Tako je 1948. sekretar komiteta KP Srbije, iz Alibunara, na sledeći način obrazložio zašto podržava izbor Valerije Pantić na mesto predsednice seoskog odbora AFŽ: „CK KPS u vezi s time doneo je odluku i kandidovao je.

${ }^{23}$ Bosa Cvetić, Komunistička partija Jugoslavije i žensko pitanje, Beograd 1960, 43.

${ }^{24} \mathrm{O}$ trećoj karakteristici je na Prvom kongresu AFŽJ govorila Vida Tomšič. Govor Vide Tomšič, AFŽJ 141-1-2, AJ.

${ }^{25}$ I pored nesumnjivo napornog i mukotrpnog rad članica AFŽ broj nepismenih žena u Jugoslaviji je porastao, pa je 1948. udeo nepismenih u ukupnom ženskom stanovništvu činio $34,4 \%$ (2.256.279), da bi pet godina kasnije, 1953, porastao na 35,8\% (2.506.475), M. Stanišić, $n$. d., 290.

${ }^{26}$ L. Sklevicky, Konji, žene, ratovi, Zagreb 1996, 119. 
Kao kandidat pokazala se dosta vredna i agilna. U sebi poseduje još dosta malograđanskih osobina, kojih se teško odvikava, i usled toga nema dovoljno upornosti, a niti pokazuje uslove da se izgradi u komunistu. Na osnovu njenog autoriteta koji uživa među Rumunskim masama i na osnovu rada u organizaciji AFŽ, CK KPS mišljenja je da se postavi za predsednicu Sreskog odbora AFŽ". ${ }^{27}$

Ipak, u ideološkom, programskom, organizacionom i, razume se, finansijskom pogledu, reč je o organizaciji koja je u okvirima Narodnog fronta pripadala nesumnjivo među onima koje su najčvršće bile povezane sa Komunističkom partijom Jugoslavije i državnim vlastima. U instrukcijama izdatim AFŽ posle završetka rata isticana je potreba organizovanja rada sa ženama u okviru Narodnog fronta. Odbori AFŽ trebalo je da postanu sekcije odbora Narodnog fronta. ${ }^{28} \mathrm{U}$ rukovodstvu AFŽJ bile su istaknute članice KPJ i bivše partizanke, ${ }^{29}$ i tokom postojanja organizacije nije se dogodilo da ona na bilo koji način dođe u sukob sa vlastima, ili u nesaglasje s politikom partije. O tome svedoči i "kritika“ koju je, obraćajući se prisutnima na Prvom kongresu AFŽ, izrekao Josip Broz. „Ako dozvolite da se kritički osvrnem na izvesne nedostatke i slabosti, kako na rad rukovodstva ove velike ženske organizacije tako i na držanje jednog dela, razume se malog dela žena, koje nisu svesne svojih dužnosti, ili se nemarno odnose prema zajednici. Ovde ja ne mislim na onaj mali broj gospođa i gospođica po gradovima... Ja mislim na onaj drugi mali deo žena koje misle da su za vreme rata dovoljno dale od sebe za novu Jugoslaviju, bilo u borbi, bilo na radu u pozadini - i sada ne učestvuju ni na raznim radovima u korist naroda, ni u društvenom životu, već se posvetiše samima sebi. Na taj način, takve žene postepeno spadaju u red onih žena koje ne shvataju novo društvo već čeznu za laganim životom, bez naročitih briga i rada. Često takve žene poprimaju navike žena neradnica iz starog društva“". ${ }^{30}$

Zapisnici sa Prvog plenuma Centralnog odbora Antifašističkog fronta žena (CO AFŽJ) jasno ukazuju na odlučnost njegovih predvodnica da ne dopuste da ova organizacija postane pretežno humanitarna ustanova.

${ }^{27}$ Spiskovi i pregled članstva u društvenim organizacijama, CK SKS, Komisija za kadrove, kutija br. 29, AS.

${ }^{28}$ Problemi društvenog položaja i aktivnosti žena, Beograd 1965, 8-9.

${ }^{29}$ U predsedništvu Centralnog odbora bile su veteranke partizanskog rata: Spasenija Babović, Mitra Mitrović Đilas, Persa Prodanović, Milica Dedijer, Razumenka Petrović, Jara Ribnikar, dr Olga Milošević, Milica Stajić, Anka Berus, Kata Pejnović, Maca Gržetić, Olga Kovačević, Vanda Novosel, Vida Tomšič, Pepca Kardelj, Lepa Perović, Mara Naceva, Blagoja Demnijeva, Veselinka Malinska i Lidija Jovanović. Treba napomenuti da su supruzi $20 \%$ navedenih žena u to vreme bili na visokim državnim i partijskim dužnostima. U Centralnom odboru bilo je 76 članica, izabranih na Prvom kongresu AFŽJ-a.

${ }^{30}$ Govor Josipa Broza Tita na Prvom kongresu AFŽJ-a, AFŽJ 141-1-2, AJ. 
Budući da je rat na prostoru Jugoslavije trajao sve do uništenja poslednjeg otpora novom režimu, kao što je početak Hladnog rata do 1948. godine bio vreme velikog sukoba sa zapadnim silama, pitanje mobilizacije svih organizacija i ideološkog rada postalo je prioritetno. „Ali vi ne smete da zaboravite da se mi i dalje nalazimo u vrlo velikom ratu. Naš pokret treba na svim poljima, a naročito na ekonomskom i privrednom, uvući u borbu i ne dati mu da se pretvori u neku humanitarnu ili kakvu drugu organizaciju u kojoj će izgubiti onaj svoj borbeni revolucionarni karakter, koji je stekao svojim postupcima u toku Narodnooslobodilačkog rata." 31

Predvodnice AFŽJ ipak nisu bile zadovoljne ukupnim učinkom organizacije tokom prve posleratne godine. Iako su delovanje AFŽJ i aktivnosti žena u vreme izbora bili dobro ocenjeni, Vida Tomšič je u svom obraćanju na Prvom plenumu CO AFŽJ iznela stav da stečena ravnopravnost nije podstakla veću aktivnost žena: „Što se tiče političkog vaspitanja žena, pokazalo se da su naše žene u predizbornoj kampanji i u diskusiji o ustavu krenule čvrsto napred. Ali, iz izlaganja pojedinih drugarica moglo se osetiti da i pored toga što su žene u velikom broju izašle na izbore, uzimale učešća $u$ diskusiji o ustavu, ipak nisu pokazale neko naročito oduševljenje zbog stečene ravnopravnosti sa muškarcima." ${ }^{32}$

Do 1947. godine u ustanovama KPJ pojavilo se mišljenje da Antifašistički front žena ne deluje u skladu sa očekivanjima. U martu je, na sastanku Komisije za rad među ženama CK KPJ, zaključeno da u mnogim selima širom NR Srbije dve godine posle završetka rata nisu oformljeni mesni odbori AFŽ. Čak i tamo gde su postojali, ovi odbori su bili nedovoljno aktivni. ${ }^{33}$ Smatralo se da je rad AFŽ kampanjski, nesamostalan, da najviše ustanove AFŽ ne deluju kao rukovodstvo već kao propagandna tela, konačno, da se žene slabo odazivaju kroz aktivnosti organizacije. Komisija je, takođe, pokazala nezadovoljstvo sadržinom ženskih listova koji su pod nadzorom AFŽ izlazili u narodnim republikama. Odlučeno je da se stvaranjem novih organizacija - sekcija AFŽ - podstakne uključivanje novih članica u organizaciju. Predloženo je stvaranje tri sekcije (organizacije): Majka i dete, Društvo naprednih domaćica, Ženska zadruga za kućnu radinost ${ }^{34}$ i utvrđeno da AFŽ ne treba da postane „izolovana feministička organizacija“ već da mora da bude sastavni deo Narodnog fronta. ${ }^{35}$

${ }^{31}$ Govor Mitre Mitrović na Prvom plenumu CO AFŽJ, AFŽJ 141-6-13, AJ.

${ }^{32}$ Govor Vide Tomšič na Prvom plenumu CO AFŽJ, AFŽJ 141-6-13, AJ.

${ }^{33}$ M. Stanišić, $n$. d., 149; Tokom 1947. samo u NR Hrvatskoj prestalo je s radom čak 1.500 mesnih odbora AFŽ, koji su bili aktivni još za vreme rata. L. Sklevicky, n. d., 122.

${ }^{34}$ M. Stanišić, 149; Zapisnici sa sednica Politbiroa Centralnog komiteta KPJ ..., 45.

${ }^{35}$ M. Stanišić, $n$. d., 149. 
Uočljivo je da su ove preporuke kontradiktorne. Na jednoj strani AFŽ je zamerana neaktivnost a njegovom rukovodstvu pasivnost i nesamostalnost, dok je na drugoj AFŽ usmeravan ka Narodnom frontu i podstican da ne pođe putem feminizma. Podozrenje prema AFŽ postojalo je u ustanovama KPJ još od prvih posleratnih meseci. Tako je u jednom pismu, koje je 23. oktobra 1945. u ime Centralnog komiteta (CK) KPJ napisao Aleksandar Ranković, formulisano i sledeće upozorenje: „U nekim partijskim organizacijama radom Antifašističkog fronta žena ne rukovodi partijska organizacija kao svojim sektorom rada, već AFŽ prepušta samom sebi, ne shvatajući ogromnu snagu koju predstavlja i može da predstavlja AFŽ. U mnogim partijskim organizacijama taj rad je nedovoljan, često i nikakav, partijske organizacije ne rukovode njime, niti ga drže u svojim rukama. Zato u svakoj partijskoj organizaciji, komitetu i ćeliji treba obavezno odrediti druga ili drugaricu koji će sistematski, sa planom rukovoditi tim radom. Pri tom treba imati $u$ vidu da se na rad $u$ AFŽ mobiliše što veći broj partijki bez obzira na posao koji rade (npr. u državnom aparatu), ili na sektor rada koji u partiji imaju. “36

I u AFŽ su bili samokritični. Tako su u Izveštaju o radu AFŽ NR Srbije za razdoblje 1946-1952. uočeni brojni nedostaci: „....nepostojanje stalnog sistematskog rada, za rad među ženama nemamo još dovoljno aktivistkinja. Obična je pojava da drugarice koje su se uzdigle, ne vole da rade $u$

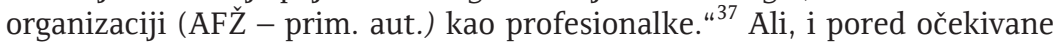
partijske samokritike, u AFŽ su se čuli glasovi koji su ukazivali na prepreke delovanju organizacije, koje dolaze od same partije i vlasti FNRJ. Tako je među dokumentima AFŽ NR Hrvatske moguće pročitati: „Narodni front takođe ne shvata specifične zadatke AFŽ i koristi ga najčešće za izvršavanje tehničkih poslova. Čitavi odbori AFŽ upotrebljeni su u kampanji samo kao tehnička lica, za potpise. Pri frontovskim radnim akcijama ne vodi se računa o specifičnim fiziološkim razlikama žena, te je bilo slučajeva teških oboljenja žena zbog neprimerenog rada. Na svojim sednicama mnogi odbori Narodnog fronta ne tretiraju pitanje organizacije AFŽ u celini, niti se interesuju za rad žena. Mnogi drugovi, rukovodioci Narodnog fronta, oficiri, rukovodioci u narodnoj vlasti, ne šalju i ne puštaju svoje žene da učestvuju u radu NF i AFŽ. “38

Na Trećem kongresu ove organizacije, održanom u Zagrebu 28. i 29. oktobra 1950, otvoreno je pitanje stapanja AFŽ u Narodni front. Predvodnice AFŽJ na ovom kongresu prvi put su postavile pitanje potpunog ulaska 70 AFŽJ, AJ.

\footnotetext{
${ }^{36}$ Zapisnici sa sednica Politbiroa Centralnog komiteta KPJ..., 306-307.

${ }^{37}$ Izveštaj o radu Organizacije AFŽ NR Srbije, od Plenuma CO AFŽ do danas, 141-13-
}

${ }^{38}$ L. Sklevicky, n.d., 124. 
AFŽJ u Narodni front. Iako se nisu protivile takvom razvoju, one su tom prilikom iznele i primedbe na račun toga da se organizacija AFŽ u aktivnostima NF upotrebljava za obavljanje tehničkih zadataka, dok se njegova politička funkcija zanemaruje. Na kongresu je govorila Vida Tomšič: „Treba istaći neke nepravilnosti koje su se pojavile na terenu u odnosu partijskih i frontovskih organizacija prema Antifašističkom frontu žena i koje su u izvesnoj meri imale za posledicu i slabost u radu među ženama... Pored toga, kod dodeljivanja zadataka AFŽ-u su se obično određivali sasvim tehnički zadaci. Tako, na primer, kod izbora, kod raznih propisa... mobilisane su aktivistkinje na rad u kancelarijama; ali im nije dat zadatak političkog rada među ženama. “39

Mara Naceva je u tekstu koji je iste godine objavljen u Partijskoj izgradnji otišla korak dalje, uočavajući da AFŽ ne samo što nije samostalan već je počeo da slabi značaj njegove političke i prosvetne uloge. „Partijska rukovodstva su“, kaže ona, „ukoliko su i pretresala pitanje rada AFŽ, pretresala to jednostrano, obično samo pitanje aktiviziranja žena na dobrovoljnim akcijama NF i drugim fizičkim poslovima, a malo se posvetilo pažnje osnovnom zadatku: političkom i širokom prosvetnom radu sa ženama. "40

Koncepcijske razlike, kad je reč o ulozi žene u socijalističkom društvu, svakako nisu ukazivale na podele u komunističkom režimu. One su, međutim, bile uočljive na samom kongresu. Tako je u svom obraćanju pred 949 delegatkinja Josip Broz govorio o „specifičnim obavezama“ žena: „Ja mislim, drugarice, da vi u prvom redu svom svojom snagom i elanom treba da vršite dužnosti koje proističu iz tih vaših specifičnih obaveza, kao što je, na primer, briga o ženama majkama, briga o higijeni dece i briga o deci uopšte, briga o zdravlju, o vaspitanju žena u Jugoslaviji, o tome da u svoju žensku organizaciju i NF okupite što veći broj još neokupljenih žena... Vi se morate boriti za svaku ženu, svaku devojku da otrgnete ispod tog negativnog uticaja i privedete je $u$ front graditelja naše socijalističke zemlje. To je vaš prvi zadatak. Vaš drugi zadatak, kao članica NF, u tome je da isto tako kao ostali članovi Fronta, ukoliko vam to vaši specifični zadaci dozvoljavaju, pomažete svuda gde je to potrebno na dobrovoljnom radu, razume se, ukoliko to dozvoljavaju fizičke i druge sposobnosti žena."“41

$\mathrm{Na}$ istom kongresu, Vida Tomšič je iznela potpuno drugačije argumente, ali i cilj organizovanja žena: „Potreba da se radu među ženama posvećuje posebna briga, da se na poseban način pristupa ženama, dakle,

${ }_{41}$ J. Broz Tito, Iz govora na Trećem kongresu AFŽJ-a, Žena u revoluciji, Sarajevo 1978, 163-164.

${ }^{39}$ Obraćanje Vide Tomšič na Trećem kongresu AFŽJ, 141-3-8, AFŽJ, AJ.

${ }^{40}$ Mara Naceva, Neka pitanja partiskog rada među ženama, Partijska izgradnja, br. 1, 
postoji zbog zaostalosti žena; zbog njihove ranije društvene potlačenosti, kao i opšte zaostalosti u shvatanju društvene uloge žene. Prema tome, cilj zbog kojeg je potreban poseban rad među ženama biće ostvaren onda kada prestane potreba takvog rada, kada žene stvarno uzmu punog učešća u svim društvenim aktivnostima, kada postanu aktivni upravljači svoje zemlje - 'kada svaka kuvarica uzme učešće u upravljanu državom', kako je kazao Lenjin." ${ }^{42}$

Rezolucija usvojena na Kongresu nije predviđala radikalne reforme organizacije. Kao slabosti AFŽ prepoznati su „šablonizam i formalizam“ u organizaciji, kao i birokratizam u rukovođenju. Kao rešenje predloženo je dalje i čvršće vezivanje za Narodni front. Buduće samostalne aktivnosti AFŽ trebalo je da se odnose na domen odnosa majki i deteta i pitanja pomoći radnica, dakle, pre svega na socijalni položaj žena. ${ }^{43}$

Vida Tomšič je ispravno zaključila da je prosečna žena preopterećena, ali je veoma zanimljivo da ona i druge diskutantkinje nisu spomenule činjenicu da su vodeće žene $u$ AFŽ, osim funkcija u ovoj organizaciji, obavljale po još nekoliko veoma odgovornih političkih funkcija $u$ isto vreme, bile su istovremeno članice rukovodećih tela sindikata, KPJ, Narodnog fronta... Tako je Mitra Mitrović u isto vreme bila članica Centralnog odbora AFŽJ, ministarka prosvete u Vladi NR Srbije, narodna poslanica u Saveznoj skupštini, članica CK KP Srbije i, takođe, članica Politbiroa CK KPS, glavna urednica Žene danas, članica Izvršnog odbora MDFŽ, a bila je i na čelu Agitpropa CK KPS. Ona sama je na pitanje kako je uspevala da obavlja tako veliki broj odgovornih funkcija $\mathrm{u}$ isto vreme odgovorila da je radila na dva koloseka, na političkom i prosvetnom, i naglasila: „Ja sam dosta rano prestala biti među najaktivnijim članovima AFŽ-a, zato što sam imala velike ove dužnosti. Bila sam, naravno, u Centralnom odboru, bila sam na kongresima, držala referate na kongresima, ali u onom sitnijem, praktičnom radu u vezi sa ženama, osim u pogledu određivanja pravca razvoja, izdvajanja osnovnih problema rada među ženama, posle godinu-dve nisam više bila u tome najaktivnija, mada sam bila stalno u rukovodstvu AFŽ samo se nisam bavila najneposrednije, vrlo praktično, problemima žena." ${ }^{44}$

Možemo da pretpostavimo da ni druge politički najaktivnije žene nisu bile u mogućnosti da jednako uspešno obavljaju sve funkcije na koje su bile postavljene. Problem je bio u tome što je nekoliko najistaknutijih žena zauzimalo veoma veliki broj profesionalnih i političkih funkcija koje nisu bile u stanju da jednako dobro obavljaju, a na taj način su zatvorile moguć-

${ }^{42}$ Obraćanje Vide Tomšič na Trećem kongresu AFŽJ-a, 141-3-8, AFŽJ, AJ.

43 Rezolucija Trećeg kongresa AFŽJ o političkim i organizacionim pitanjima, Žena danas, br. 77-78, novembar-decembar 1950, 14-15.

${ }^{44}$ Razgovor koji je sa Mitrom Mitrović vodila Kerol Lili 13. aprila 1988. 
nost drugim bivšim partizankama ili ženama stručnjacima da se aktivnije uključe u društveni život nove države: „Ima pojava da politički razvijene drugarice imaju jako mnogo odgovornih zadataka, 278 članova ima preko 8 i 10 funkcija, što s jedne strane onemogućava ulazak novih žena u komitete a sa druge strane demorališe nove pa i stare kadrove jer nisu uvek u mogućnosti da odgovore tolikim zadacima. Zatim, jedan isti broj žena pojavljuje se na nekoliko mesta i u nekoliko organa i organizacija.. ${ }^{45}$

Lidija Sklevicki, analizirajući Statut AFŽJ, zaključuje da ova organizacija vremenom postaje samo „jedan sektor partijskog rada, jedan sektor rada Fronta“ ${ }^{46}$ Ova autorka, upravo u razdoblju koje je usledilo posle 1948. godine vidi potpuno napuštanje tradicija predratnog Ženskog pokreta, čime je konačno nestala mogućnost kritike vlasti. Citirajući retoriku predvodnica AFŽ ona lapidarno zaključuje kako „žensko pitanje više ne postoji, već postoje samo pitanja koja žene rešavaju“". ${ }^{47}$

Četvrti kongres AFŽJ održan je od 26. do 28. septembra 1953. Osim transformacije organizacije, najvažnije teme bile su položaj žena na selu i politička pasivizacija žena. U izveštaju AFŽ za NR Srbiju primećena je politička pasivizacija žena i njihova sve manja prisutnost u Partiji i narodnim odborima. Tako su, na primer, u AP Vojvodini 1949. godine, odbornice činile $9,14 \%$ ukupno izabranih odbornika, dok je 1952. ovaj udeo opao na $3,81 \%$. Ovakva pojava objašnjavana je produženim postojanjem shvatanja članova Partije o neravnopravnosti žena. Obraćajući se delegatkinjama, Milovan Đilas je primetio da je stvarna ravnopravnost žena još daleko, ali je naglasio da je jačanjem demokratije i ženske ravnopravnosti u Jugoslaviji svaka posebna politička aktivnost žena postala smetnja u ostvarenju ravnopravnosti i aktivnosti žena. Đilas je smatrao da stvaranje Saveza ženskih društava (SŽD), umesto „jedne polupolitičke i polucentralizovane organizacije" kakav je bio AFŽ, predstavlja neminovnost. Prema njegovom tumačenju, ciljeve AFŽ trebalo je da preuzme celokupno društvo, a cilj budućeg SŽD trebalo je da bude pridobijanje vlasti za njihove zamisli: „Ukratko, čini mi se da bi bilo tačno ako budemo perspektivu koja je pred nama ocrtali: $\mathrm{u}$ čisto političkom radu žena ne treba da se odvaja od muškarca, tu treba da su zajedno, ravnopravni. A ukoliko žena bude društveno - kulturno, prosvetno, sindikalno, zdravstveno itd. - aktivnija, utoliko će se brže ona dizati na društveni nivo muškarca. Dakle: u politici zajedno, u ostaloj aktivnosti i odvojeno i zajedno - prema potrebi, a što šire i što svestranije - svakako, da

${ }^{45}$ Podaci o aktivnosti, nacionalnom i socijalnom sastavu žena članova sreskih $i$ opštinskih komiteta, CK SKS Komisija za kadrove, kutija br. 29, AS.

${ }^{46}$ L. Sklevicky, n. d., 132.

${ }^{47}$ Isto, 133. 
bi se i muškarci i žene, čitavo društvo, kretali ka stvarnoj demokratiji, ka socijalizmu, ka stvarnoj ravnopravnosti žena." ${ }^{48}$

Svakako ključne argumente u prilog reformisanju AFŽJ pružila je Vida Tomšič tvrdeći da je dotadašnji način organizovanja, prema kojem je AFŽ monopolizovao društvene i političke aktivnosti svih žena, postao neodgovarajući. Ona, kao logične naslednike AFŽ vidi različita ženska društva koja će se baviti određenim pitanjima koja se direktno tiču poboljšanja položaja žena u društvu. U svom izlaganju Vida Tomšič je istakla da takva društva već postoje. ${ }^{49}$ Nijedna od navedenih organizacija nije se bavila pitanjem političke emancipacije žena, već su sva društva, kao glavni cilj, iz različitih aspekata, isticala rešavanje problema majke i deteta.

$\mathrm{Na}$ osnovu argumenata koje su govornici izneli, Četvrti kongres je ukinuo AFŽ i istovremeno osnovao Savez ženskih društava. U Rezoluciji o stvaranju Saveza ženskih društava Jugoslavije, sačinjenoj na ovom kongresu, naglašeno je da je „stvar ženske ravnopravnosti zajedničko društveno pitanje, to je pitanje opšte borbe svih snaga socijalizma koje predvodi Savez komunista i Socijalistički savez radnog naroda, nosilac socijalističkog vaspitanja masa. " ${ }^{400} \mathrm{U}$ Rezoluciji, takođe, podvučen je stav po kojem žene ne treba da se odvajaju u posebne političke organizacije. Prema istraživanju Nede Božinović, dok su u gradovima pozdravljali ovu odluku, u selima su žene dugo posle ukidanja AFŽ negodovale zbog toga: „Pričale su o tome kako njihovi muškarci likuju. Govorili su im: 'Dosta je vašeg bilo!' Ili: 'Gotovo je, gotovo!' Ili: 'Nema više.' Isticale su da se muškarci stalno okupljaju, imaju svoje kafane, fudbal, pa i Narodni front, dok njih više niko ne okuplja, a željne su da štogod čuju i razgovaraju o svojim - ženskim problemima. "

Za emancipaciju žena u prvim posleratnim godinama, od velikog je značaja i priroda velikih ekonomskih promena i najvećeg demografskog pomeranja stanovništva ka gradovima $\mathrm{u}$ istoriji jugoslovenskih naroda. Većina među 2.000 nezaposlenih Beograđanki registrovanih 1952. godine, prema analizama AFŽ, nisu imale profesionalne kvalifikacije, a mnoge su bile nepismene. ${ }^{52}$ Ovih činjenica i njihove političke i ekonomske dimenzije bile su svesne i tadašnje državne i partijske ustanove. Na Drugom kongresu

\footnotetext{
${ }^{48}$ Milovan Đilas, Za stvarnu ravnopravnost žena, (obraćanje M. Đilasa IV kongresu AFŽJ), Partijska izgradnja, br. 9 , Beograd 1953, 227-229.

${ }^{49}$ To su bila društva za unapređenje domaćinstva, društvo za prosvećivanje žena i majki, kao i društva za stvaranje dečijih ustanova, školskih kuhinja, za brigu o vaspitanju i zdravlju dece...; V. Tomšič, Mesto i uloga ženskih organizacija, Zora, br. 89-90, oktobar-novembar 1953, 5.

${ }^{50}$ Rezolucija o stvaranju Saveza ženskih društava Jugoslavije, Zora, br. 89-90, oktobar-novembar 1953, 9

${ }^{51}$ Neda Božinović, Žensko pitanje u Srbiji u XIX i XX veku, Beograd 1996, 174.

${ }^{52}$ В. Гудац Додић, Жена у соиијализму..., 58.
} 
AFŽJ-a Vida Tomšič je u svom referatu konstatovala da se delovanje AFŽJ vremenom smanjivalo. Zamerala je bivšim partizankama neaktivnost, ali i povlačenje sa dužnosti koje su ranije, za vreme rata, sa uspehom obavljale. Opravdanje za ove pojave videla je u povratku partizanki mirnodopskom životu i porodicama. Zato je predlagala pojačavanje političkog rada. ${ }^{53}$

Socijalni profil žena koje su učestvovale u javnom i političkom životu posleratne Jugoslavije nije unificiran. Najznačajnije političke funkcije zauzimale su partizanke ali osim njih žene iz gradova, naročito iz industrijskih centara, svakako su bile prisutnije u javno-političkoj sferi od onih sa sela. Manji stepen aktivnosti žena sa sela bio je uslovljen većim stepenom nepismenosti kao i većim prisustvom patrijarhalnog koncepta porodičnih odnosa. U institucije vlast birane su žene različitog socijalnih porekla. Tako je u Skupštini NR Srbije, od 102 poslanice, bilo 35 radnica, 31 intelektualka, 29 seljanki, 7 žena zanatlija. ${ }^{54} \mathrm{U}$ lokalnim organima vlasti znatan procenat zauzimale su domaćice, dok su se u većima proizvođača srezova i gradova nalazile uglavnom radnice. Tako možemo zaključiti da je, posmatrano kroz pripadnost određenim društvenim grupama, u državnim i društvenim institucijama bilo najviše radnica, za njima su sledile intelektualke, pa domaćice, dok su seljanke zauzimale poslednje mesto.

Sve naše sagovornice saglasne su da žene nisu bile jednako zastupljene u državnim i partijskim ustanovama i većina njih takvo stanje opravdava činjenicom da u to vreme nije bilo dovoljno obrazovanih žena koje bi mogle da odgovore zahtevima visokih dužnosti. ${ }^{55}$ Olga Ninčić Humo ima malo konzervativnije mišljenje od ostalih: „Ako su žene mogle da se izbore za svoju poziciju onda su uspevale da se nametnu. Ali, ipak su jači bili muškarci, i brojno, i po znanju, i po borbenosti. Uvek su bile iste žene na funkcijama. Nije bilo šta da se utiče. One su formalno imale sva moguća prava, ali nisu bile dovoljno snažne da ih iskoriste. Ono par žena što je bilo u rukovodstvu, one su uvek govorile. Nisu muškarci tu bili krivi nego same žene se nisu borile nizašta, nije to bilo neko oduševljenje, ništa naročito."

Politička emancipacija žena posle u posleratnoj Jugoslaviji odvijala se u specifičnim okolnostima jednopartijskog sistema. Žene su 1945. godine dobile opšte pravo glasa ali su na izborima mogle da biraju isključivo između članova i članica Komunističke partije, tako da je demokratski kapacitet njihovih bazičnih političkih prava bio u mnogome ograničen. Prve jugoslo-

${ }^{53}$ Isto.

54 141-12-16, AFŽJ, AJ.

${ }^{55} \mathrm{Na}$ pitanje da li su svi muškarci koji su zauzimali visoke funkcije bili adekvatno obrazovani, naše sagovornice odgovarale su uglavnom odrečno, ali je, prema njihovom uverenju, prednost muškaraca bila brojnost.

${ }^{56}$ Razgovor sa Olgom Ninčić Humo, vođen 21. jula 2007. 
venske političarke bile su bivše partizanke. One su birane na određene političke funkcije po principu popunjavanja kvota i nisu se u državnim institucijama, osim kroz rad AFŽ, zalagale za izjednačavanje rodnih uloga.

Ukidanje AFŽ može se uzeti kao studija slučaja o političkoj aktivnosti i stepenu postignute emancipacije žena u prvim posleratnim godinama. Analizom raspoložive arhivske građe i savremene periodike, naročito glasila AFŽ, jasno se uočava nedovoljan stepen samostalnosti u radu i odlučivanju, kod rukovoditeljki AFŽ. Sve istaknute političarke još u leto 1953. govore o budućim projektima i aktivnosti ove organizacije i iz njihovih izjava se nikako ne može uočiti čak ni ideja o ukidanju AFŽ. Već u septembru 1953, međutim, te iste žene odlučno kritikuju rad AFŽ i energično se zalažu za rasformiranje organizacije i neophodnost stvaranja više ženskih organizacijama sa različitim poljima delovanja, koje su isključivo usmerene na humanitarni rad i podršku u roditeljstvu. Nepotrebnost daljeg postojanja objašnjavale su činjenicom da su žene u komunističkoj Jugoslaviji pravno potpuno izjednačene sa muškarcima i da je dobijanjem prava glasa i ulaskom $u$ političke institucije njihova politička emancipacija u potpunosti završena. Iz navedenih analiza i statističkih podataka možemo zaključiti da je ovo ipak trebalo da bude tek početak političke emancipacije žena u posleratnoj Jugoslaviji, da su one u poslevolucionarnim državno-političkim institucijama bile simbolično zastupljene i da je njihov politički aktivizam sveden na minimalni nivo u najvećoj meri kanalisan i kontrolisan kroz rad AFŽ.

Pored svih navedenih nedostataka političke emancipacije žena, mora se istaći i činjenica da je ženama na ovim prostorima u komunističkoj Jugoslaviji prvi put omogućeno da se samostalno uključe u politički život jugoslovenskog društva, za njih do tada potpuno nov i apsolutno neosvojiv diskurs. Dok su u Kraljevini Jugoslaviji u političkom životu mogle učestvovati isključivo kao pasivne pratilje svojih muških partnera: braće, očeva, prijatelja, muževa sada im je makar i u ograničenim okolnostima omogućeno samostalno, javno, aktivno političko delovanje. Žene su delom svojim aktivnostima $u$ antifašističkom, partizanskom pokretu tokom rata ova prava same sebi izborile. 
Ivana Pantelić

\section{CONQUERING THE UNCONQUERABLE: POLITICAL EMANCIPATION OF WOMEN IN POSTWAR YUGOSLAVIA 1945-1953}

\section{Summary}

The period 1944-1948 was marked by rapid development of realsocialist regime. Women had a significant role in this process. Demobilized members of Partisan Army moved into cities in large numbers during the first post-war years. By a number of acts adopted in Yugoslavia and its newly-established republics, women became equal with men, following the model already applied in the USSR. Emancipation of women was, together with state, economic and social reforms, carried out with the help of the Party and the army. Women took part in elections for the first time in 1945. They were given the full - active and passive - suffrage. The proportion of women in the organs of new authorities was the same as in institutions of the partisan state during the war. At the same time, there were no women in the federal government, while there was one woman minister in governments of the republics of Serbia, Croatia and Slovenia. Mitra Mitrović was the Minister of Education in Serbia, Anka Berus the Minister of Finance in Croatia and Vida Tomšič the Minister of Social Politics in Slovenia. All three of the first women ministers were partisans and members of the Partisans during the war. The most important organization which, as part of the People's Front, assembled women was the Women's Antifascist Front of Yugoslavia. Women's presence in the political institutions was absolutely symbolic and purely formal. In that authoritarian society they shared the same role as their male colleagues, their political goals were ideological but the institution called Women's Antifascist Front of Yugoslavia symbolically enabled women to publicly advocate for their rights. 